\title{
An Enhanced Model For E-Service Quality of Mobile Banking
}

\author{
Jude N. Owuamanam ${ }^{1 *}$, Salfarina Abdullah ${ }^{2 *}$, Yusmadi Yah Jusoh ${ }^{3}$, Noraini Che $\mathbf{P a}^{4}$ \\ ${ }^{1,2,3,4}$ Department of Software Engineering and Information System, \\ Faculty of Computer Science and Information Technology, Universiti Putra Malaysia, 43400 UPM Serdang, \\ Selangor,Malaysia \\ ndymok1@gmail.com ${ }^{1}$, salfarina@upm.edu.my ${ }^{2}$
}

Article History: Received: 10 November 2020; Revised: 12 January 2021; Accepted: 27 January 2021;

Published online: 05 April 2021

\begin{abstract}
The increasing growth in mobile device users and the rapid drop in conventional and mobile data charges have given way for a provision of banking services and mobile banking to be precise. Banks are now extending their services from traditional means of banking to a self-service system. Recently, mobile banking has been growing exponentially, but there is still a lack of confidence by the users because of low e-service quality of mobile banking. Researchers have done many works on mobile banking but were focused more on adoption and user intentions which contributes to the marketing and promotion of mobile banking. Mobile banking has some specific characteristic which makes it different from other web-based eservices. So the previous studies lack specific in-depth mobile banking e-service quality, such as failure to define the eservice quality of mobile banking and identification of mobile banking dimensions. This study identified mobile banking's dimensions and attributes that received less attention and suggested an improved model for mobile banking's electronic service quality.
\end{abstract}

Keywords:Mobile banking, E-service quality.

\section{Introduction}

Internet growth and innovations have changed how financial services are used and delivered (Laukkanen, 2016), particularly when mobile banking technology and mobile internet are taken into consideration. The set of new platforms provided by banks (Calisir, F., \& Gumussoy, 2008) can now focus on mobile banking (Mohammadi, 2015). Mobile banking is the use of mobile devices to access wireless banking services (Afshan \& Sharif, 2016). It suggests that mobile banking customers will use mobile devices to conduct various payment functions, including payments, transfers, account enquiries, and account applications (Zhou, 2012a).. The exponential growth of mobile devices has a positive impact on mobile banking demand (Veríssimo, 2016). Although a lot has been done to improve the public's understanding of the adoption of mobile banks and the eservices quality in the last few years, customers still face problems with the mobile banking services because of the low level of e-service quality in their mobile banking services ( $\mathrm{Yu}, 2015)$. The purpose of this study is to examine all the main relevant aspects of mobile banking electronic services that require immediate attention.

\section{LiteratureReview}

Information system e-service quality is the digital contact between the service provider and the customers, the customers interact directly with the system, and such service form depends on web-services, mobile services and portal. Van Dyke et al. ( 1997) is one of the first researchers to relate the quality of service assessment to the information system. SERVQUAL was adopted by the same researchers to assess the quality of service in an information system (Van Dyke et al., 1999). The emergence of the new concept of electronic service quality model by (Parasuraman et al.,2005) with the dimensions efficiency, system availability, fulfilment, privacy, and assurance was the first generally accepted model to measure electronic service quality. Several other models for assessing the quality of service in the digital environment have emerged such asWEBQUAL(BarnessandVidgen;2000,2001a,2001b,2002) for measuring the quality of a website such as a web portal, SITEQUAL(Webb and Webb;2001,2004) for evaluating site quality such as online shopping and online bookstores, and IRSQ(Janda et al.,2002) for measuring online service quality of online retailers.

E-S-QUAL/E-RECS-QUAL (Parasuraman et al., 2005) is a category of the model that measures all the online service quality. However, it does not focus only on the design elements of the website or a particular issue but general issues for effective electronic service quality. The model is divided into two, such as E-S-QUAL and E-RECS-QUAL. E-S-QUAL has the dimensions of efficiency, system availability, fulfilment, privacy, assurance which is called the e-core dimensions (T. Padmapriya et al, 2020). The E-RECS-QUAL which has dimensions of responsiveness, compensation and contact, and it is used to measure the electronic service recovery. It can also measure e-banking, e-shopping, mobile services, etc. SSTQUAL (Lin and Hsienh, 2011), the authors narrated SST as "technological interfaces that enable customers to produce a service independent of direct service employee involvement" this implies that it is a form of electronic service, where customers as 
physical, interact with a technical machine. Example performing a transaction using automated teller machine (ATM).

With the rapid growth and increase in penetration of mobile services, many organizations are adopting mobile services to their businesses and transactions. The following models have been developed by some researchers to help measure the service quality of mobile service quality. M-S-QUAL (Huang et al., 2015), which has the dimensions: responsiveness, contact, privacy, privacy, efficiency and fulfilment. Rajeev Kumar (2017) developed a model called MAPPSQL with its dimensions of Design, functionality, assurance, customization, fulfilment. It can as well measure any mobile application service quality. The model can be modified by any organization or sector for any mobile application services in accordance with the organizational requirement for service quality (Rajeev Kumar, 2017).

Table 1. Existing dimension of e-service quality of mobile banking

\begin{tabular}{|c|c|c|}
\hline Author'sname/Year & $\begin{array}{l}\text { E-service quality } \\
\text { dimension }\end{array}$ & Model used \\
\hline $\begin{array}{l}\text { Geeta Sharmaand } \\
\text { SurendraMalviya }(2014\end{array}$ & $\begin{array}{l}\text { Reliability,responsiveness,assurance,convenience } \\
\text {,security and efficency }\end{array}$ & E-S-Qual/E-RecS-Qual \\
\hline $\begin{array}{l}\text { Haba Khalid Asfour } \\
\text { and } \quad \text { Shafig } \\
\text { Haddad,2014 }\end{array}$ & $\begin{array}{l}\text { Reliability, flexibility, privacy, accessibility, } \\
\text { easy to navigate, efficiency and security }\end{array}$ & E-S-Qual \\
\hline $\begin{array}{l}\text { Ghosh Kumar Sagib } \\
\text { and BaruaZapan(2014) }\end{array}$ & $\begin{array}{l}\text { Reliability,responsiveness, } \\
\text { assurance,security,convenience, efficiency and } \\
\text { easiness to operate }\end{array}$ & E-S-Qual/E-RecS-Qual \\
\hline $\begin{array}{l}\text { V.MallikarjunaandS.R } \\
\text { eddyMurali(2014) }\end{array}$ & $\begin{array}{l}\text { Reliability, responsiveness, easy for access, } \\
\text { communication, security/privacy, user friendly, } \\
\text { efficiency /speed }\end{array}$ & E-S-Qual/E-RecS-Qual \\
\hline Surendra et al.,(2015) & $\begin{array}{l}\text { Assurance/security,efficiency/convenience,respo } \\
\text { nsiveness, reliability,satisfactory }\end{array}$ & E-S-Qual \\
\hline VahidelAlipoor(2016) & $\begin{array}{l}\text { Responsiveness,reliability,assurance/security, } \\
\text { efficiency/convenience }\end{array}$ & E-S-Qual \\
\hline $\begin{array}{l}\text { CarlostamandTiago } \\
\text { oliveira(2016) }\end{array}$ & $\begin{array}{l}\text { information quality/service quality, task } \\
\text { characteristic, technology characteristic and } \\
\text { System quality, }\end{array}$ & $\begin{array}{l}\text { ISSM/TTF: information } \\
\text { system success model/Task } \\
\text {-technology model }\end{array}$ \\
\hline Rahman et al.(,2017) & $\begin{array}{l}\text { Reliability,Tangibility, Responsiveness, } \\
\text { Assurance, Empathy,satisfactory }\end{array}$ & SERVQUAL \\
\hline $\begin{array}{l}\text { Mohammad Damabi et } \\
\text { al,2018) }\end{array}$ & $\begin{array}{l}\text { System quality, information quality and } \\
\text { interfacequality }\end{array}$ & $\begin{array}{l}\text { ISSM: information system } \\
\text { success model }\end{array}$ \\
\hline M-C.Tsai et al(2018) & $\begin{array}{l}\text { Efficiency,system } \\
\text { availability,fulfilment,Privacy, assurance, } \\
\text { Responsiveness, compensation, contact and } \\
\text { personalisation }\end{array}$ & E-S-Qual/E-RecS-Qual \\
\hline $\begin{array}{l}\text { Sujeet } \\
\text { nd }\end{array}$ & $\begin{array}{l}\text { Service quality, information quality, system } \\
\text { quality andtrust. }\end{array}$ & $\begin{array}{l}\text { ISSM: information system } \\
\text { success model }\end{array}$ \\
\hline
\end{tabular}

\section{Methodology}

Literature review analysis was used to conduct this study. Papers describing the mobile banking e-service quality from2014to2019wasidentifiedandreviewedtocomeupwiththe researchgap.

After a review of the existing model, it is understood that researchers have done some worksoneservicequalityofmobilebanking.Moreover,thoughseveraldimensionshavebeen suggested importance in mobile banking e-service quality assessment, very little attention has been given to most of the key mobile banking dimensions and attributes. Mobile banking application has some unique characteristics which make it different 
from web banking application. Most of the models reviewed lack the unique dimensions and attributes of the mobile banking application, such as app design, functionality, and customization. The app design is a unique dimension of a mobile banking application that gives aesthetic appealing, standardization of navigation. Another app design attribute is the user interface, which is a touchsensitivethatallowstheusertointeractwiththemobilebankingcontentsandfunctions. Functionality is another unique dimension of mobile banking, where the device compatibility enables the task to be performed in a different operating system. The customization is also a unique dimension allowing users to create their personal preferences for transactions. Despite the researchers' efforts on mobile banking's e-service quality, the unique dimensions of mobile banking's e-service quality still need to be identified. However, and none of the researchers integrated MAPPSQL (Rajeev Kumar, 2017) into their studies to determine the quality of mobile banking's eservice delivered.

MAPPSQL is very generic in nature, which has the dimensions that can accommodate different requirements for the e-service quality of mobile applications. It contains both the unique dimension (App design, functionality, customization) and core (assurance, fulfillment, service recovery) dimensions that can effectively assess and measure mobile application

eservice.Mobileappswillbeacrucialcomponentinservingcustomersaffectivelyinthefuture due to the high penetration of mobile phone users. MAPPSQL has been proven to be effective in assessing the electronic service quality of e-commerce, e-wallet and e-government portal application systems (Rajeev Kumar, 2017).

MAPPSQL is adopted and modified in this study to assess the quality of electronic service offered by mobile banking. App design, functionality, customization, assurance, fulfillment, service recovery are all the dimensions of MAPPSQL.In order to match up the attributes of mobile banking, the dimensionofspeedisadded. Whenacustomerisusingtechnology devicesto perform transaction, speed is a very important factor for the customer (Bateson 1985, V.Mallakarjumar et al., 2014). However, after the experts' assessments and reviews of the dimensions, security is added to complete the dimension and attributes of eservice quality of mobile banking. Security is the usage of service that is considered as the most significant characteristic within the target segments when deciding to choose mobile banking (Haba Khalil Asfour and Shafic,2014).

\section{Proposed Enhanced Model For E-Service Quality of Mobile Banking}

The Research Model's DimensionsDescriptions of Figure 1 are:

1, APP design: The design consists of the attractive visual interface of the service and the use of new equipment to ease the service process (Lin \& Hsieh, 2006). The design of the technology-based service help to improve the service of the mobile application. The application/software should be aesthetically built to appeal to the use of the service in technology-based services. The app design is the tangibility dimension of e-service (Rajeev Kumar,2017)

2, Functionality: it is a dimension that consists of effectiveness, efficiency and error-free performance of a service of in technology-based service. Functionality is when the function of service works perfectly to achieve a great performance. In the context of electronic service, it represents system availability (Parasuraman et al., 2005) and in terms of internet service, it represents the performance of service (Yen, 2005, Hussain et al. 2016).

3, Assurance: Assurance is inspired by representation of truthful information (Parasuraman et al.,2005) Reputation and good image of every organization represent the assurance in a Service (Lin \& Hsieh,2006). It is that ability of the service provider to inspire confidence and trust to their customers on the service that are being delivered.

4, Customization: Customers would want to use services at their own requirements and convenience (Lin \&Hsieh 2006). It is also the extent of providing exclusive personal service by the system (Parasuraman et al.,2005 and Swaid \& Wigand,2009). As a result of this, many studies have considered customization highly related with the service quality of service provider.

5, Fulfilment: It is the ability of the service provider deliver services as promised and timely (Parasuraman et al., 2005). This is when an organization try to live up to the services promised to customers. Making sure that the promises made to customers are fulfilled and timely. 


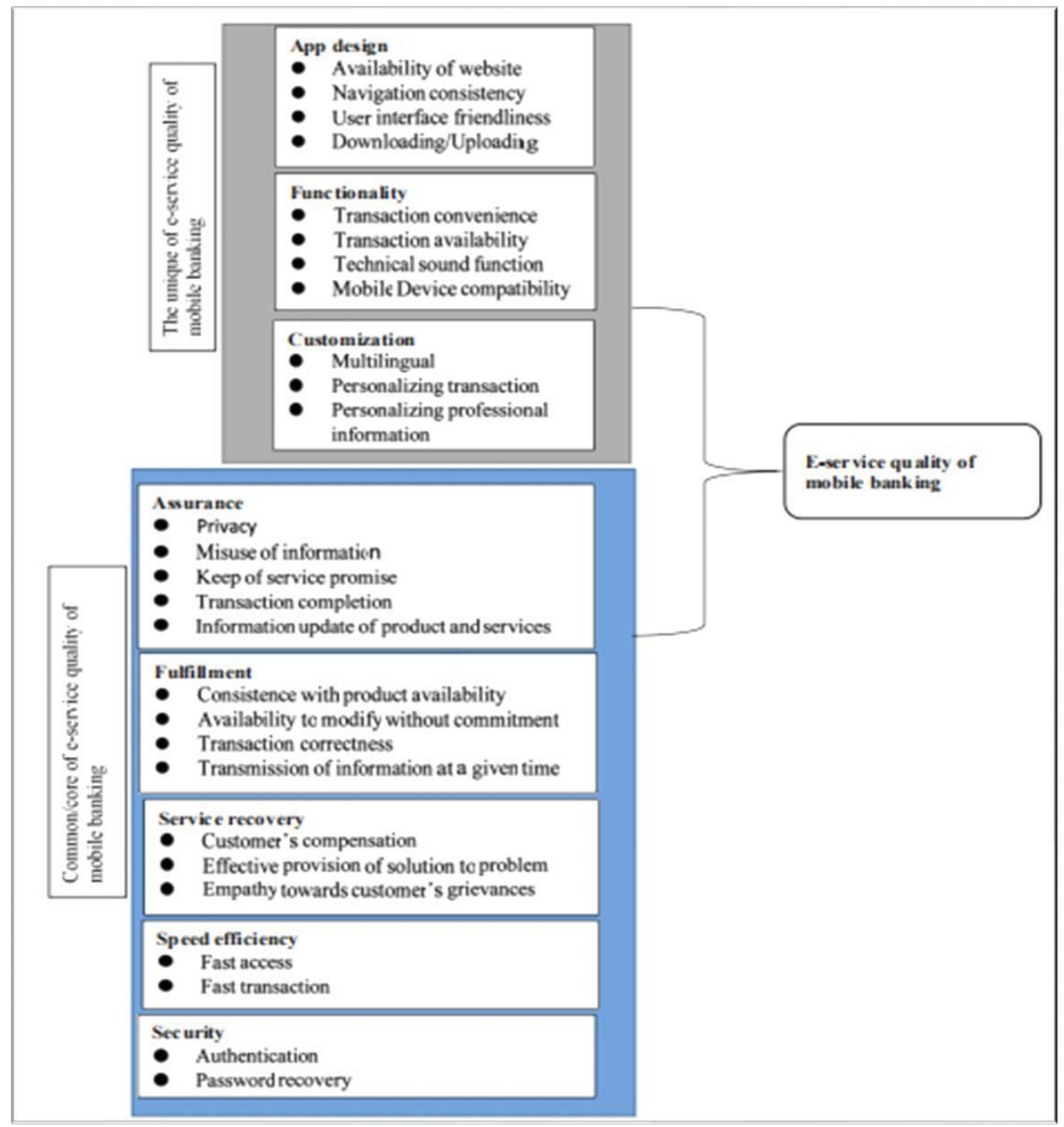

Figure 1.Proposed enhanced model for e-service quality of mobile banking

6, Service recovery: This is when an organization tries so hard to make sure that services are delivered accordingly, but failures are always inevitable. Many times, services come shortly as per customers' requirements. So, the way service providers respond to service failure with an effective service recovery plays a major role in customer's satisfaction. Organization are making sure that a service delivery process robust enough but failures are inevitable (Parasuraman et al., 2005, Rajeev Kumar, 2017).

7, Speed efficiency: The rate at which data and applications are being processed. All the transaction process should be quick and fast. When a customer uses technology devices to perform a transaction, speed becomes an important factor for the customer (Bateson, 1985). Speed refers to the rate of performance in mobile banking operations (V. Mallikarjuna and S.Reddy Murali (2014).

8, Security: It is the usage of service that is considered as the most significant character within the target segments when deciding to choose mobile banking (Haba Khalil Asfour and Shafic, 2014). Security is the means of protecting users from the risk of phishing, fraud and hacking (Dhiraji Sharma and Singh Khurmi2015, 
Hussain et al. 2015). This is the level at which mobile device apps are protected from cracking, malware and other criminal activities.

\section{Conclusion}

While many studies of mobile banking focus on the adoption and intention to use, this study focuses on the identification of the key e-service quality dimensions and attributes of mobile banking that have not been given adequate attention. Mobile banking has some certain dimensions and attributes, which makes it different from other web-based e-services. This study integrated MAPPSQL model, which is generic in nature that has dimensions and attributes that can accommodate different requirements for e-service quality of mobile banking. The dimensions of the MAPPSQL are app design, functionality, assurance, customization, fulfillment, and service recovery. Speed efficiency is added because it is a significant factor for consumers when using technology as a form of service. However, after the experts' assessments and reviews of the dimensions, security is added to complete the dimension and attributes of mobile banking's e-service quality. These dimensions are essential in terms of assessing mobile banking e-service quality. The research proposed an enhanced model for assessing the e-service quality of mobile banking based on the eight dimensions of e-service quality that were identified. The further study ought to taken up to design and test a scale based on these dimensions.

\section{References}

1. Afshan, S., \& Sharif, A. 2016. Acceptance of mobile banking framework in Pakistan. Telematics and Informatics, 33:370-387.

2. Barnes, S. J., \& Vidgen, R. 2001a. An evaluation of cyber-bookshops: the WebQual method. International Journal of Electronic Commerce, 6(1): 11-30.

3. Barnes, S. J., \& Vidgen, R. T. 2001b. Assessing the quality of auction web sites. In System Sciences, 2001. Proceedings of the 34th Annual Hawaii International Conference on IEEE, (pp. 10-pp).

4. Barnes, S. J., \& Vidgen, R. T. 2002. An integrative approach to the assessment of e- commerce quality. J. Electron. Commerce Res., 3(3):114-127.

5. Barnes, S.J., and Vidgen, R.T. 2000. WebQual: An exploration of Web site quality. In Proceedings of the Eighth European Conference on Information Systems. Vienna, July 3-5, 2000.

6. Bateson, J., .1985. Perceived control and service encounter, IN: The service encounter managing employee/customer interaction, service businesses.

7. Bhatiasevi, V. 2015. An extended UTAUT model to explain the adoption of mobile banking. Information Development, 1-16 Published online before print.

8. Calisir, F., \& Gumussoy, C. A. 2008. Internet banking versus other banking channels: Young consumers' view. International Journal of Information Management, 28: 215-221.

9. Carlos Tam and Tiago.2016.understand the impact of $\mathrm{m}$-banking on individual performance: Delone\&Mclean and TTF perspective, computer in human behaviour.

10. Geeta Sharma and Surrendra.2014. Exploring the dimension of mobile banking service quality.

11. Heba Khalil Asfour1 \& Shafig I. Haddad2 .2014.The Impact of Mobile Banking on Enhancing Customers' E-Satisfaction: An Empirical Study on Commercial Banks in Jordan, International Business Research, 7: 1913-9012.

12. Huang, E. Y., Lin, S. W., \& Fan, Y. C. 2015. MS-QUAL: mobile service quality measurement. Electronic Commerce Research and Applications, 14(2):126-142.

13. Hussain, A., Abubakar, H.I., Hashim, N.B. (2015). Evaluating mobile banking application: Usability dimensions and measurements. Conference Proceedings - 6th International Conference on Information Technology and Multimedia at UNITEN. ICIMU 2014, art. no. 7066618, pp. 136-140.

14. Hussain, A., Mkpojiogu, E.O.C. (2016). Requirements: Towards an understanding on why software projects fail. AIP Conference Proceedings, 1761, art. no. 020046.

15. Janda, S., Trocchia, P. J., \& Gwinner, K. P. 2002. Consumer perceptions of Internet retail service quality. International Journal of Service Industry Management, 13(5): 412-431.

16. Laukkanen, T. 2016. Consumer adoption versus rejection decisions in seemingly similar service innovations: The case of the Internet and mobile banking. Journal of Business Research, 69:2432-2439.

17. Lin, J. S. C., \& Hsieh, P. L. 2011. Assessing the self-service technology encounters: development and validation of SSTQUAL scale. Journal of Retailing, 87(2):194-206.

18. Lin, J., \& Hsieh, P. 2006. The role of technology readiness in customers' perception and adoption of self-service technologies. International Journal of Service Industry Management, 17: 497.

19. M-c.tsai et al, .2018. Upgrading service quality of mobile banking, int .J. Mobile communication, 6: 1 
20. Mohammad Damabi et al.,.2018.A model for customers satisfaction and trust for mobile banking using Delone and mclean model of information system success, journal of soft computer and decision support system, $5: 3$.

21. Mohammadi, H. 2015. A study of mobile banking loyalty in Iran. Computers in Human Behavior, 44: 35-47.

22. Parasuraman, V.A. Zeithaml, and A. Malhotra .2005. E-S-QUAL: A multiple-item scale for assessing electronic service quality. Journal of Service Research, 7 (3):213-234.

23. Rahman et al., .2017. Mobile banking service quality and customer satisfaction in Bangladesh: An analysis, the cost and management, 45, 2: 1817-5090.

24. Rajeev Kumar. 2017. A proposed scale of assessing mobile app service quality, 2349-2317.

25. Sagib, Ghosh Kumar and Zapan, Barua.2014. Bangladeshi mobile banking service quality and customer satisfaction and loyalty, Management \& Marketing, 9:3-5.

26. Sharma, S. K. 2017. Integrating cognitive antecedents into TAM to explain mobile banking behavioural intention: A SEM-neural network modelling. Information Systems Frontiers, 1-13.

27. Sujeet Kumar and Manisha. 2019. Examining the role of trust and quality in the actual usage of mobile banking services: empirical investigation, international journal of information management.

28. Surendra Malviya.2015.Exploring Mobile Banking Service Quality Dimensions for Public and Private Sector Banks in Indore District of Madhya Pradesh, International Journal of Advance Research in Computer Science and Management Studies, 3, 1: 2327782

29. Swaid.S.I and Wigand.R.T. 2009. Measuring the quality of e-service: scale development and initial validation. Journal of electronic commerce research, 10, 1:13-28.

30. T. Padmapriya \& S.V. Manikanthan, "Retracted: Security and Routing protocol for 5 G wireless mobile networks". IJIMT, 2020.

31. V.Mallikarjuna and S.Reddy Murali 2014. Conceptual model for assessing service quality of mobile banking, Indian journal of applied research, 4, 4:2249-555.

32. Validel Alipoor 2016. Effect of service quality of mobile banking and technology on customer brand image, int.J. Of comp. \& InfoTech, 4, 1: 2345-3877.

33. Van Dyke, T. P., Kappelman, L. A., \& Prybutok, V. R.1997. Measuring information systems service quality: concerns on the use of the SERVQUAL questionnaire. MIS quarterly, 195-208.

34. Van Dyke, T. P., Prybutok, V. R., \& Kappelman, L. A.1999. Cautions on the use of the SERVQUAL measure to assess the quality of information systems services. Decision sciences, 30(3): 877-891.

35. Veríssimo, J. M. C. 2016. Enablers and restrictors of mobile banking app use: A fuzzy set qualitative comparative analysis (fsQCA). Journal of Business Research, 69:5456-5460.

36. Webb, H. W., \& Webb, L. A. 2004. SiteQual: an integrated measure of Web site quality. Journal of Enterprise Information Management, 17(6): 430-440.

37. Webb, H., \& Webb, L. 2001. Business to consumer electronic commerce Website quality: integrating information and service dimensions. AMCIS 2001 Proceedings, 558-562.

38. Yen, H. 2005. An attribute-based model of quality satisfaction for Internet self-service technology. The Service Industries Journal, 25: 641-659.

39. Zeithaml, V. A., Parasuraman, A., \& Malhotra, A. 2002. Service quality delivery through web sites: a critical review of extant knowledge. Journal of the academy of marketing science, 30(4): 362- 375.

40. Zhou, T. 2012a. Understanding users' initial trust in mobile banking: An elaboration likelihood perspective. Computers in Human Behaviour, 28: 1518-1525. 